\title{
The Importance of Family Education on The Formation of Social Attitude And Independence of Children in The Industrial Revolution 4.0
}

\section{Linda Safitri, Naenul Muna, Rizki Kurnianto}

Universitas Sebelas Maret

linsafitrida@gmail.com

\section{Article History}

accepted 24/09/2019

approved 01/10/2019

published 01/12/2019

\begin{abstract}
Children's social awareness in Indonesia tends to be still low. This can be seen from the emergence of difficulties children develop social attitudes in themselves, such as the attitude of cooperation and socializing with their environment. In fact, social attitudes and independence are needed in the future. Therefore family education is the most important education to shape social attitudes and independence of children. This study aims to explain the importance of family education towards the formation of social attitudes and children's independence. This study uses the results of studies from journals and books collected and then described and analyzed. The conclusion of this study is that Family Education influences the Formation of Social Attitudes and Children's Independence in the Industrial Revolution Era 4.0.
\end{abstract}

Keywords: social attitude, independence, family education

\begin{abstract}
Abstrak
Kesadaran sosial anak di Indonesia cenderung masih rendah. Hal ini dapat dilihat dari timbulnya kesulitan anak mengembangkan sikap sosial dalam dirinya, seperti sikap kerjasama dan bersosialisasi dengan lingkungannya. Padahal, sikap sosial dan kemandirian sangat dibutuhkan di masa yang akan datang. Oleh karena itu Pendidikan keluarga merupakan Pendidikan yang paling utama untuk membentuk sikap sosial dan kemandirian anak. Kajian ini bertujuan untuk menjelaskan pentingnya Pendidikan keluarga terhadap pembentukan sikap sosial dan kemandirian anak. Kajian ini menggunakan hasil kajian dari jurnal dan buku yang terkumpul dan kemudian dideskripsikan dan dianalisis. Kesimpulan kajian ini adalah Pendidikan Keluarga berpengaruh terhadap Pembentukan Sikap Sosial dan Kemandirian Anak di Era Revolusi Industri 4.0.
\end{abstract}

Kata kunci: sikap sosial, kemandirian, Pendidikan keluarga

Social, Humanities, and Education Studies (SHEs): Conference Series https://jurnal.uns.ac.id/shes

p-ISSN 2620-9284

e-ISSN 2620-9292 


\section{PENDAHULUAN}

Saat ini, Pendidikan keluarga sangat dibutuhkan dalam membentuk sikap sosial yang baik bagi anak. Pendidikan Keluarga adalah pendidikan pertama yang dilaksanakan orang tua terhadap anak untuk membentuk perannya di dalam kehidupan bermasyarakat. Hasil dari pendidikan yang didapatkan oleh anak dalam keluarga berpengaruh dalam menentukan pendidikan bagi anak itu selanjutnya. Dalam kehidupan keluarga, orang tua mempunyai peranan ganda yaitu pertama mendidik anaknya dalam upaya sosialisasi untuk penanaman sikap sopan santun, menanamkan nilai-nilai, perasaan kasih sayang antar sesama, norma-norma dalam masyarakat dan lain sebagainya.

Ahmadi (2009__menyatakan bahwa sikap sosial merupakan kesadaran individu yang menentukan perilaku nyata dan berulang-ulang terhadap obyek sosial". Sikap sosial ini tidak dinyatakan oleh seorang melainkan diperhatikan oleh orang-orang sekelompoknya. Pengembangan sosial yang baik, seperti tolong-menolong, kerjasama, berbagi, simpati, empati, dan saling membutuhkan satu sama lain merupakan arah dari penanaman sikap sosial pada anak. Anak pada dasarnya cenderung meniru, menyontek serta secara tidak langsung menggurui pola sikap sosial kedua orang tuanya.

Kemandirian sangat penting untuk diperkenalkan kepada anak sedini mungkin. Dengan kemandirian tersebut anak akan terhindar dari sifat ketergantungan pada orang lain, dan yang terpenting adalah menumbuhkan keberanian dan motivasi pada anak untuk terus mengekspresikan pengetahuan-pengetahuan baru. Ali dan Asrori (2015:110), menyatakan Kemandirian adalah suatu kekuatan internal yang didapatkan melalui proses realisasi kemandirian dan proses menuju kesempurnaan". Kemandirian merupakan aspek yang berkembang dalam diri setiap individu, yang wujudnya sangat beragam, bergantung pada proses perkembangan dan proses belajar yang dialami masing-masing individu (Sunarty, 2016).

Pendidikan keluarga mempunyai peranan yang penting terhadap pembentukan sikap sosial dan kemandirian anak. Karena pembentukan sikap sosial dan kemandirian dapat dibentuk melalui Pendidikan keluarga yang baik. Pendidikan keluarga mampu membentuk sikap yang baik bagi anak agar mampu berinteraksi dan beradaptasi dilingkungan sekitarnya.

Berdasarkan uraian diatas, maka permasalahan yang akan dibahas dalam kajian ini yaitu bagaimana peran Pendidikan Keluarga terhadap Pembentukan Sikap Sosial dan Kemandirian pada anak.

\section{A. Sikap Sosial}

\section{HASIL DAN PEMBAHASAN}

Sikap sosial adalah kesadaran seseorang atau individu yang dapat menentukan suatu perbuatan yang nyata dan berulang-ulang terhadap suatu obyek sosial. Sikap sosial tersebut tidak dinyatakan oleh seorang namun diperhatikan oleh beberapa orang di sekelompoknya. (Ahmadi dalam Virani, dkk., 2016). Sikap sosial ini sangat penting sebagai modal utama bagi seorang anak untuk menyatakan perannya ke dalam lingkungan dan masyarakat. Terdapatnya sikap sosial ini tentu sangat dipengaruhi oleh macam faktor kepentingan dari individu sendiri guna memenuhi kebutuhan dasar.

Menurut Shochib (2010:15) Sikap sosial pada seorang anak diarahkan untuk pengembangan sosial yang sangatb baik, yaitu kerjasama, tolong menolong, berbagi, simpati, empati, dan saling membutuhkan antar manusia. Dengan ini, sasaran pengembangan suatu perilaku sosial anak untuk keterampilan berkomunikasi, keterampilan, mempunyai rasa senang, dan memiliki tata krama baik. Menurut Hurlock (2017:118) mengelompokan perilaku sosial anak ke dalam suatu pola - pola perilaku yakni: 
a. Meniru, yakni supaya sama dengan kelompoknya, seorang anak akan meniru sikap dan tindakan seseorang yang dia kagumi.

b. Persaingan, yakni suatu keinginan untuk mengungguli dan mengalahkan orang lain. Persaingan ini sudah tampak di usia 4 tahun. Anak akan bersaing dengan temannya dalam meraih prestasi dan berlomba-lomba memperoleh juara dalam beberapa permainan.

c. Kerja sama, dimulai pada usia tahun ketiga akhir, anak mulai bermain bersama kooperatif serta kegiatan kelompok akan mulai berkembang dan meningkat baik dalam frekuensi tertentu maupun lamanya berlangsung, bersamaan dengan meningkatkan kesempatan bermain dengan anak- anak lain.

d. Simpati, karena simpati sangat membutuhkan pengertian mengenai perasaan - perasaan emosi serta orang lain. Hal ini maka terkadang timbul sebelum tiga tahun.

e. Empati, tidak beda dengan simpati , empati membutuhkan pengertian tentang perasaan serta emosi orang lain.

f. Membagi, yakni anak mengetahui salah satu cara memperoleh persetujuan sosial yaitu membagi miliknya, contoh

g. mainan untuk anak - anak lainnya.

\section{B. Kemandirian}

Ali dan Asrori (2015:110), menyatakan "Kemandirian merupakan suatu kekuatan internal yang diperoleh dalam proses realisasi kemandirian dan proses menuju kesempurnaan". Kemandirian belajar adalah suatu faktor untuk menentukan keberhasilan siswa dalam belajar, sikap mandiri sangat penting dimiliki oleh siapa saja yang ingin mencapai kesuksesan hidupnya. Orang tua mempunyai peran yang penting untuk membentuk kemandirian diri anaknya, termasuk kemandirian belajar. Kemandirian seharusnya diperkenalkan kepada anak dariawal atau dini. Kemandirian anak ini akan menghindarkan sifat ketergantungan terhdap orang lain, dan terpenting ialah menumbuhkan keberanian serta motivasi pada anak untuk mengekspresikan pengetahuan-pengetahuan baru. Menurut (Susanto, 2013:15) sikap mandiri yakni sikap dan perilaku seseorang yang mencerminkan perbuatan cenderung pribadi / individual (mandiri), tanpa membutuhkan bantuan dan pertolongan dari orang lain.

Menurut Bacharuddin Mustafa (2008: 75) kemandirian ialah kemampuan untuk mengambil pilihan serta menerima konsekuensi dan menyertainya. Kemandirian anak terwujud ketika menggunakan pikiran sendiri untuk mengambil keputusan; seperti dilihat dari memilih perlengkapan belajar akan digunakannya, memilih teman dalam bermain, sampai hal-hal yang relative rumit dan menyertakan konsekuensikonsekuensi tertentu yang akan serius.

Berdasarkan pendapat yang telah disajikan sebelumnya, ciri-ciri karakter mandiri yakni:

1. Percaya diri sendiri

Percaya diri ialah meyakini bahwa kemampuan dan penilaian diri sendiri untuk melakukan tugas serta memilih pendekatan yang efektif.

2. Mampu bekerja sendiri

Mampu bekerja sendiri, yakni usaha yang sekuat tenaga dilakukan mandiri untuk menghasilkan membanggakan dalam kesungguhan dan keahlian yang dimiliki. 
3. Menghargai waktu

Manusia yang mempunyai sifat yang mandiri tidak membiarkan waktunya terbuang percuma dan semaksimal mungkin ia akan mengerjakan sesuatu yang bermanfaat untuk dirinya serta lingkungannya.

4. Bertanggung jawab

Tanggung jawab ialah kesadaran dalam diri seseorang bahwa pada setiap tindakan akan mempengaruhi bagi orang lain ataupun dirinya sendiri.

5. Memiliki hasrat bersaing maju

Setiap anak memiliki sikap tidak mudah membuat patah semangat dalam menghadapi segala rintangan, serta selalu bekerja keras untuk mewujudkan suatu tujuan, menganggap rintangan dan hambatan agar selalu ada di setiap kegiatan yang harus dihadapi.

6. Mampu mengambil keputusan dengan baik

Di kehidupan sehari-hari, orang tidak terlepas berbagai suatu permasalahn yang segera di selesaikan dengan baik, tepat serta seksama.

\section{Peran penting Pendidikan keluarga}

Istilah keluarga dengan pendidikan merupakan komponen yang tak terpisahkan.

Di dalam sebuah keluarga terdapat pendidikan. Saat orang tua mendidik anaknya, maka anak akan mendapatkan pendidikan dari orang tua. Untuk itu muncul "pendidikan keluarga". Dengan demikian, pendidikan yang terjadi di dalam sebuah keluarga yang dilakukan orang tua merupakan bentuk kewajiban dan tanggung jawab sebagai tugas dalam mendidik anak di dalam sebuah keluarga.

Pendidikan keluarga sangat berpengaruh dalam membentuk sikap sosial dan kemandirian anak terutama di era revolusi industry 4.0 sekarang. Melalui Pendidikan dalam keluarga dapat membentuk sikap sosial dan kemandirian anak. Hal ini sesuai dengan hal yang dikemukakan oleh Setiati (2015) Keluarga sangat berperan dalam mengembangkan pribadi anak khususnya dalam membentuk sikap sosial dan kemandirian anak. Orang tua dengan perhatian dan rasa kasih sayang selalu memberikan pendidikan tentang nilai-nilai kehidupan, baik agama maupun sosial budayanya agar anak memiliki pribadi yang baik dan menjadi anggota masyarakat yang bermanfaat. Banyak nilai-nilai di kehidupan yang dapat diajarkan oleh orang tua dalam membentuk anaknya agar mampu bersosialisasi dengan lingkungan dan masyarakat serta berjiwa mandiri. Di dalam pendidikan keluarga bukan saja dapat membuat seorang anak mempunyai sikap yang baik, tetapi juga dapat berbaur dan bersosialisasi dengan baik dengan yang lainnya. Dalam keluarga orang tua akan menanamkan karakter untuk anaknya sejak dini karena ini merupakan salah satu pondasi sebagai kontrol internal pada diri anak. Ubah lingkungan di mana sang anak itu tumbuh jadi lingkungan yang memberi teladan baik. Lingkungan inilah yang terutama membentuk sikap sosial dan kemandirian dalam diri anak itu. Membangun sikap social dan kemandirian diperlukan juga semacam reward and punishment untuk sang anak, terutama di sekolah. Jika ia berlaku baik, beri semacam "hadiah" apa pun bentuknya, entah itu apresiasi atau apa pun. Jika ia berlaku tidak baik, beri juga ia hukuman. Lingkungan dan reward and punishment ini nantinya akan menjadi semacam kontrol eksternal (sosial) pada diri sang anak, yang lazimnya jauh lebih efektif ketimbang sekadar kontrol internal dalam membentuk sikap social dan kemandirian baik anak. 


\section{SIMPULAN}

Berdasarkan pembahasan diatas maka dapat disimpulkan bahwa Pendidikan keluarga adalah Pendidikan yang pertama bagi anak. Pendidikan keluarga memiliki peran penting dalam membentuk sikap sosial dan kemandirian anak. Terdapat berbagai nilai-nilai kehidupan yang dapat diajarkan oleh orang tua dalam membentuk anaknya agar mampu bersosialisasi dengan lingkungan dan masyarakat serta berjiwa mandiri. Nilai -nilai social ini antara lain seperti kerjasama, tolong menolong, berbagi, simpati, empati, dan saling membutuhkan satu sama lain. Sedangkan nilai-nilai kemandirian yang dapat diajarkan kepada anak antara lain percaya diri, mampu bekerja sendiri, menghargai waktu, bertanggung jawab, memiliki hasrat bersaing untuk maju, dan mampu mengambil keputusan. Dengan pendidikan keluarga bukan saja dapat membuat seorang anak mempunyai sikap yang baik, tetapi juga dapat berbaur dan bersosialisasi dengan baik dengan yang lainnya.

\section{DAFTAR PUSTAKA}

Ahmadi, Abu. (2009). Ilmu Sosial Dasar. (edisi kelima). Jakarta: PT. Rineka Cipta.

Ali, M., dan Asrori, M. (2015). Psikologi Remaja: Perkembangan Peserta Didik. (edisi keempat). Jakarta: PT. Bumi Aksara.

B. Elizabeth, Hurlock. (2017). Psikologi Perkembangan. (edisi kelima) Jakarta: Erlangga

Baharudin dan Moh. Makin. (2017). Pendidikan Humanistik (Konsep, Teori, dan Aplikasi Dalam Dunia Pendidikan). Yogyakarta: Ar-Ruzz Media

Setiati, D. R. (2015). PERAN PENDIDIKAN KELUARGA DALAM PEMBENTUKAN

SIKAP SOSIAL DAN KEMANDIRIAN ANAK. Seminar Nasional Universitas PGRI Yogyakarta 2015

Shochib, Moch. (2010). Pola Asuh Orang Tua Untuk Membantu Anak Mengembangkan Disiplin Diri. (edisi kedua). Jakarta: PT Rineka Cipta

Sunarty, Kustiah. (2016). HUBUNGAN POLA ASUH ORANGTUA DAN KEMANDIRIAN ANAK. Diunduh dari https://media.neliti.com/media/publications/177109-IDhubungan-pola-asuh-orangtua-dan-kemandir.pdf Pada tanggal 9 September 2019

Virani, I. A. D, dkk. (2016). DESKRIPSI SIKAP SOSIAL PADA SISWA KELAS IV SD NEGERI 4 PENARUKAN KECAMATAN BULELENG KABUPATEN BULELENG. Diakses dari http://ejournal.undiksha.ac.id pada tanggal 26 September 2019 